\title{
Seasonal changes in growth and condition of anchovy late larvae explained with a hydrodynamic-biogeochemical model simulation
}

\author{
Eudoxia Schismenou ${ }^{1,2, *}$, Kostas Tsiaras ${ }^{3}$, Maria I. Kourepini' ${ }^{2}$, Eugenia Lefkaditou ${ }^{4}$ \\ George Triantafyllou ${ }^{3}$, Stylianos Somarakis ${ }^{1}$ \\ ${ }^{1}$ Hellenic Centre for Marine Research, Institute of Marine Biological Resources and Inland Waters, Thalassokosmos, \\ 71003 Heraklion, Crete, Greece \\ ${ }^{2}$ Department of Biology, University of Crete, 71409 Heraklion, Crete, Greece \\ ${ }^{3}$ Hellenic Centre for Marine Research, Institute of Oceanography, Mavro Lithari, 19013 Anavissos, Greece \\ ${ }^{4}$ Hellenic Centre for Marine Research, Institute of Marine Biological Resources and Inland Waters, Aghios Kosmas, \\ 16610 Helliniko, Greece
}

\begin{abstract}
We studied seasonal changes in otolith and somatic growth and condition of anchovy Engraulis encrasicolus late larvae $(8-55 \mathrm{~mm})$ from the North Aegean Sea (eastern Mediterranean), hatched during the peak (summer) and end (autumn) of, and also after (winter), the regular anchovy spawning period in the area. Mean growth rate and somatic condition were compared with abiotic and biotic parameters collected in situ (current environment). Additionally, we used the output of a coupled 3D hydrodynamic-biogeochemical model implemented over the broader sampling area to reconstruct the potential conditions that the larvae experienced during their development (environmental history). Growth in length was similar for larvae in summer and autumn $\left(0.80 \mathrm{~mm} \mathrm{~d}^{-1}\right)$ but significantly lower in winter $\left(0.63 \mathrm{~mm} \mathrm{~d}^{-1}\right)$. Larval and otolith size at hatching were larger in winter. Otolith microstructure was faint in winter with very narrow increments. Otolith and somatic growth were coupled in autumn and winter, but in summer, when temperature was high, otoliths were significantly larger for the same fish length, age and weight. The biogeochemical model simulation implied that mean plankton productivity was significantly higher during the development of larvae in summer, explaining their higher growth in weight and somatic condition compared to autumn and winter. In situ measured environmental parameters represented a snapshot of ambient conditions at the site and time of sampling and did not adequately explain the seasonal differences in growth and condition.
\end{abstract}

KEY WORDS: Engraulis encrasicolus $\cdot$ Growth $\cdot$ Otolith microstructure $\cdot$ Northeastern Aegean Sea $\cdot$ POM-ERSEM

Resale or republication not permitted without written consent of the publisher

\section{INTRODUCTION}

Small pelagic fish are characterized by large interannual fluctuations in recruitment (Fréon et al. 2005). A major factor implicated in the survival of the larval stage and subsequent recruitment is growth rate. Bigger and faster-growing larvae are more likely to survive due to higher chances of avoiding predation and/or encountering their prey, but also because they are vulnerable to predation for a shorter period of time ('bigger is better' and 'stage duration' hypotheses; Anderson 1988, Houde 1989, Leggett \& DeBlois 1994). Growth rate is determined mainly by temperature and food availability (Heath 1992). In 
multiple spawning pelagic fish with protracted spawning periods, like the European anchovy Engraulis encrasicolus (spring to autumn; Somarakis et al. 2004), larvae may experience different temperature and trophic conditions depending on the time of hatching (spring, summer or autumn), and consequently, different growth and survival opportunities. A temporal dimension in recruitment, which is linked, among other factors, to temperature and productivity cycles, has generally been poorly understood (Cargnelli \& Gross 1996).

The growth of European anchovy early larvae has been largely studied in the Mediterranean Sea (Palomera et al. 2007, Somarakis \& Nikolioudakis 2007, and references therein). Growth of late larvae and juveniles has only recently become a subject of study, and the issue of seasonal variations in growth has been addressed in only a few instances (La Mesa et al. 2009, Aldanondo et al. 2010, 2011, Costalago et al. 2011). Furthermore, even though the microstructure of anchovy otoliths has been examined thoroughly and the daily deposition pattern has been validated in both larvae and juveniles (Palomera et al. 1988, Cermeño et al. 2003, 2006, 2008, Aldanondo et al. 2008), scarce information is available on how it changes between seasons (La Mesa et al. 2009, Costalago et al. 2011). Otolith growth in European anchovy has been used in coupled hydrodynamic/ larval fish individual-based models as a proxy of somatic growth, assuming that otolith and somatic growth are proportional (Allain et al. 2003, 2007). However, uncoupling of somatic and otolith growth rates in the presence of high temperatures has been repeatedly reported in other fish species (e.g. Mosegaard et al. 1988, Folkvord et al. 2004).

In this study, we examined seasonal variations in otolith microstructure and growth rate of anchovy late larvae from the north Aegean Sea and their relationship to seasonal changes in oceanographic features. In growth studies, in situ data on the abiotic and biotic environment, i.e. data collected concomitantly with fish samples, can be used to infer the environmental conditions experienced by the fish and to explain observed differences in growth rates. This type of information, however, provides a temporary picture of the environment, representing, at most, the conditions that fish experienced for the very short period prior to and during sampling. However, for late larvae and juveniles and/or in periods when the oceanographic environment is changing rapidly (e.g. in spring), current measurements may not be representative of the actual conditions that the fish experienced during their development and that may have ultimately determined the mean growth rate in the larval/juvenile sample. In addition to using in situ collected environmental information, we also explored the use of a 3D coupled hydrodynamic-biogeochenical model implemented in the North Aegean Sea (Politikos et al. 2011, Tsiaras et al. 2012) to assess the environmental conditions that the larvae may have experienced during their development and provide a better understanding of the causes of seasonal changes in mean growth rate and somatic condition.

\section{MATERIALS AND METHODS}

\section{Sample collection}

Sampling of anchovy late larvae took place at a coastal site ( 30 m depth) of the North Aegean Sea, in front of the mouth of the Nestos River (Fig. 1), in July 2007 (summer), December 2007 (autumn) and February 2009 (winter; Table 1). A small pelagic trawl with a $7 \mathrm{~m}$ vertical opening and $8 \mathrm{~mm}$ mesh size (knot-to-knot) in the cod-end was used on board the RV 'Philia'. Sampling details are provided by Nikolioudakis et al. (2011). Fish were fixed in $10 \%$ boraxbuffered formalin ( $\mathrm{pH} \geq 8.8-8.9$ ) immediately after capture and subsequently preserved in new formalin

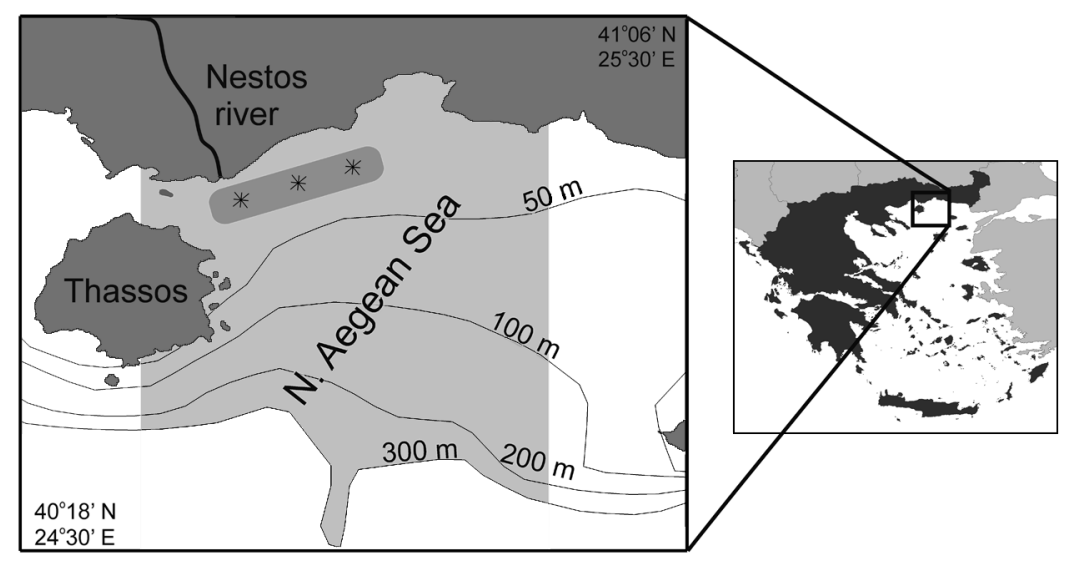

Fig. 1. Study site, indicating the trawling area (long, rounded rectangle) and the location of the 3 stations for hydrographic and plankton sampling (asterisks). The shaded rectangle marks the area over which outputs of the coupled hydrodynamic/biogeochemical model (POM-ERSEM) implemented in the North Aegean Sea were averaged 
Table 1. Summarized information on fish samples and environmental conditions from summer 2007 (S07), autumn 2007 (A07) and winter 2009 (W09). N: number of late anchovy larvae with analysed otoliths. SL: standard length. Arithmetic means and F-values are provided for environmental parameters. Asterisks indicate the level of significance: ${ }^{* *} p<0.01,{ }^{* * *} p<0.001$. Results of the Student-Newman-Keuls tests are also given: $\mathrm{a}>\mathrm{b}>\mathrm{c}$

\begin{tabular}{|c|c|c|c|c|}
\hline & $\mathrm{S} 07$ & A07 & W09 & $F$ \\
\hline Sampling dates & 27-31 July 2007 & 8-11 December 2007 & 10-17 February 2009 & \\
\hline $\mathrm{N}$ & 140 & 129 & 104 & \\
\hline $\mathrm{SL}(\mathrm{mm})$ range & $8-31$ & $18-44$ & $25-55$ & \\
\hline Hatch date range & $\begin{array}{l}16 \text { June- } \\
15 \text { July } 2007\end{array}$ & $\begin{array}{c}14 \text { October- } \\
17 \text { November } 2007\end{array}$ & $\begin{array}{c}30 \text { November 2008- } \\
4 \text { January } 2009\end{array}$ & \\
\hline Surface $(5 \mathrm{~m})$ temperature $\left({ }^{\circ} \mathrm{C}\right)$ & $26.45^{\mathrm{a}}$ & $14.11^{\mathrm{b}}$ & $11.16^{\mathrm{c}}$ & $14130.10^{* * *}$ \\
\hline Surface $(5 \mathrm{~m})$ salinity & $34.37^{\mathrm{b}}$ & $36.61^{\mathrm{a}}$ & $36.41^{\mathrm{a}}$ & $176.03^{* * *}$ \\
\hline Mean chl $a$ in the water column $\left(\mu g l^{-1}\right)$ & $0.14^{\mathrm{c}}$ & $1.36^{\mathrm{a}}$ & $0.76^{\mathrm{b}}$ & $25.90^{* * *}$ \\
\hline Mesozooplankton biomass $\left(\mathrm{mg} \mathrm{m}^{-3}\right.$ ) & $29.02^{\mathrm{b}}$ & $36.4^{\mathrm{a}}$ & $28.05^{\mathrm{b}}$ & $63.15^{* * *}$ \\
\hline Microzooplankton biomass $\left(\mathrm{mg} \mathrm{m}^{-3}\right)$ & $32.18^{\mathrm{c}}$ & $91.04^{\mathrm{b}}$ & $130.73^{\mathrm{a}}$ & $5.74^{* *}$ \\
\hline
\end{tabular}

solution, within $<24 \mathrm{~h}$ after fixation. The preservative was checked regularly thereafter to ensure that $\mathrm{pH}$ remained higher than 8.6 (Dulcic 1995).

In addition to fish sampling, temperature, salinity and fluorescence profiles were taken over the mean trawling path with a Seabird 25 CTD, at 3 equally spaced stations (Fig. 1). At the same stations, mesoand microzooplankton samples were also collected using a WP2 net (mouth opening: $0.255 \mathrm{~m}^{2}$; mesh size: $200 \mu \mathrm{m}$ ) and a scaled-down version of the same sampler (mouth opening: $0.05 \mathrm{~m}^{2}$; mesh size: $50 \mu \mathrm{m}$ ), respectively. The size fractions from 50 to $200 \mu \mathrm{m}$ and from 200 to $2000 \mu \mathrm{m}$ were used for biomass estimations of microzooplankton and mesozooplankton, respectively. Depth-stratified water samples were also collected for chlorophyll a ( $\mathrm{chl}$ a) determination. More details are provided by Nikolioudakis et al. (2011).

\section{Otolith preparation and analysis}

In the laboratory, a length-stratified subsample of anchovy larvae was selected for otolith analysis representing the entire length range of larvae collected in each survey (Table 1). Standard length (SL) and total weight (TW) were measured to the nearest $0.1 \mathrm{~mm}$ and $0.0001 \mathrm{~g}$. No correction was applied for length shrinkage, which was considered negligible for this size range (La Mesa et al. 2009).

The sagittal otoliths of the smaller larvae (SL < $35 \mathrm{~mm}$ ) were extracted from each fish under a stereomicroscope equipped with polarizing filters. The otoliths of the larger specimens were removed using the 'up through the gills' method (Secor et al. 1992). All otoliths were cleaned from adhering tissues and mounted on glass slides using thermoplastic resin.
Most otoliths of larvae with SL up to $30-35 \mathrm{~mm}$ did not need any further processing. The remainder were ground down with a $12 \mu \mathrm{m}$ lapping film and then polished with $1 \mu \mathrm{m}$ lapping film. After heating and repositioning of the otolith, the procedure was repeated for the other side until a thin sagittal section was obtained in which the nucleus and all increments were visible. The degree of polishing was checked regularly under the microscope to avoid over-polishing.

The right or left otolith was randomly selected from each fish for otolith microstructure analysis. Otoliths were observed under a light microscope, and immersion oil was used to enhance image clarity. The finer increments at the central area (nucleus) of the otolith were read at $1000 \times$ magnification, while the rest of the otolith was read at $200 \times$. Calibrated digital images of the otoliths showing the increments from nucleus to the periphery of the post-rostrum were obtained through a CCTV camera connected to an image analyser (Image-Pro Plus 3.0, Media Cybernetics). The maximum otolith radius $(\mathrm{OR}, \mu \mathrm{m})$ from nucleus to post-rostrum was measured, daily increments were marked along the $\mathrm{OR}$, and widths of individual increments were calculated by the use of a specific algorithm of Image-Pro Plus. Daily increment interpretation followed the methodology proposed by Cermeño et al. (2008). All otoliths were read independently by 2 readers, and the readings were only accepted if $100 \%$ agreement was reached.

\section{Age and growth}

The daily pattern of increment deposition in anchovy has been validated for both larvae (Aldanondo et al. 2008) and juveniles (Cermeño et al. 2003). 
Furthermore, Aldanondo et al. (2008) demonstrated that increment deposition starts at hatching. Thus, individual age from hatching was deduced from the number of increments. Hatch dates were simply calculated by subtracting the number of increments from the sampling date (Aldanondo et al. 2010; Table 1).

The relationships between SL, TW, OR and age were calculated in order to determine mean growth rate and somatic condition of fish for each season. The respective relationships were compared among seasons using analysis of covariance (ANCOVA) models (Somarakis et al. 1997). Multiple contrasts were used to test for significant pairwise differences between slopes or intercepts (Somarakis \& Nikolioudakis 2007).

\section{Biophysical model outputs}

Additional information on the mean oceanographic conditions in the study area during the period that the larvae were growing (recent environmental history) was obtained by outputs of a 3D coupled hydrodynamic-biogeochemical model (Politikos et al. 2011, Tsiaras et al. 2012) simulation in the North Aegean Sea over the same period.

The hydrodynamic model is based on the Princeton Ocean Model (POM, Blumberg \& Mellor 1983) which is a $3 \mathrm{D}$, primitive equation, free-surface circulation model. POM employs a bottom-following sigmacoordinate system, which is particularly suitable for coastal applications. It is a widely spread community model that has been previously implemented in the North Aegean (Kourafalou \& Barbopoulos 2003, Kourafalou \& Tsiaras 2007) and is part of the 'POSEIDON' operational forecast system (Nittis et al. 2006, Korres et al. 2010).

The biogeochemical model is based on the European Seas Ecosystem Model (ERSEM, Baretta et al. 1995) and was adopted by Petihakis et al. (2002) after further calibration/validation against available remote sensing and in situ data (Tsiaras et al. 2010, 2012, Politikos et al. 2011). ERSEM is a comprehensive 'functional' type model that describes pelagic and benthic ecosystem dynamics, taking into account all of the important processes operating both at the physiological and community level, such as growth, respiration, lysis, excretion, mortality and grazing. The ecosystem's biota is grouped together according to their functional role and size class. The pelagic ecosystem is represented by 4 phytoplankton groups (diatoms, nanoplankton, picoplankton, dinoflagellates), 3 zooplankton (heterotrophic nanoflagellates, microzooplankton, mesozooplankton), bacteria and dissolved and particulate organic matter (Triantafyllou et al. 2005). The coupled model (POM-ERSEM) implemented in the North Aegean for this study is similar to the coupled biophysical Mediterranean basin scale model that is currently operational within the Poseidon Forecast System (www.poseidon.hcmr. gr; Tsiaras et al. 2010).

An inter-annual simulation of POM-ERSEM in the North Aegean Sea provided selected oceanographic parameters as daily average values in the broader area of sampling (Fig. 1) from January 2007 to February 2009. The atmospheric forcing for the simulation was obtained from POSEIDON (Papadopoulos et al. 2002). The water discharge for major North Aegean rivers (including the Nestos River) was set to climatological mean values (Therianos 1974) with maximum runoff during the spring period (Poulos et al. 1997). River nutrient concentrations were based on yearly mean in situ data (Skoulikidis 2009).

In order to verify the simulated seasonal variability, the model surface chl $a$, averaged over the study area, was compared against remotely-sensed chl a (MODIS). Remotely-sensed chl a data may be characterized by significant uncertainties in coastal, river-influenced areas, due to the presence of other coloured substances (IOCCG 2000), such as coloured dissolved organic matter, which cannot be readily distinguished from chl a with the employed algorithms. Therefore, we focussed our comparison on seasonal variability, rather than absolute chl a magnitude. For this purpose, chl a was normalized to standard deviation (SD) units:

$\operatorname{normalized}(\operatorname{chl} a)=[\operatorname{chl} a-\operatorname{mean}(\operatorname{chl} a)] / \operatorname{SD}(\operatorname{chl} a)$

Larvae produced over the NE Aegean Sea continental shelf are largely retained there, close to the spawning sites, as indicated by field studies (Somarakis \& Nikolioudakis 2007) and particle tracking models (S. Somarakis unpubl.). We therefore considered that larvae captured in this study had originated from sites close to the sampling area and had not been advected from distant spawning locations. In that sense, averaging POM-ERSEM parameters over the broader sampling area would most likely adequately represent the average conditions that individuals experienced while growing, at least for the purpose of inter-seasonal comparisons. Model parameters were averaged over the shaded area in Fig. 1, either from shore to the $50 \mathrm{~m}$ isobath or from shore to the $300 \mathrm{~m}$ isobath. The parameters included: sea surface $(3 \mathrm{~m})$ temperature $\left(\mathrm{SST}^{\circ}{ }^{\circ} \mathrm{C}\right)$, sea surface $(3 \mathrm{~m})$ salinity (SSS), potential energy deficit (PED, J; a 
measure of vertical density stratification, Planque et al. 2007), integrated $(0-100 \mathrm{~m}) \mathrm{chl} \mathrm{a}\left(\mathrm{mg} \mathrm{C} \mathrm{m}^{-2}\right)$, integrated $(0-100 \mathrm{~m})$ mesozooplankton (MesoZ, mg C $\left.\mathrm{m}^{-2}\right)$ and integrated $(0-100 \mathrm{~m})$ microzooplankton (MicroZ, $\mathrm{mg} \mathrm{C} \mathrm{m}^{-2}$ ) biomass.

Seasonal changes in mean growth rate and somatic condition were compared with average model outputs, i.e. recent environmental history, for: (1) the period $30 \mathrm{~d}$ before the first sampling date, (2) the period prior to sampling equal to maximum reported age in the larval sample and (3) a $30 \mathrm{~d}$ period centred around the date calculated by subtracting the average age of larvae in the sample from the first day of sampling. Preliminary analysis (not shown) indicated that seasonal trends and the results of all subsequent comparisons between larval data and environmental conditions were similar regardless of the spatial or temporal option of averaging model parameters. We therefore present only results concerning average model predictions for the area from shore to the $300 \mathrm{~m}$ isobath and the period prior to sampling equal to the maximum age of larvae (option 2 above).

Seasonal differences in the in situ measured environmental parameters as well as averaged POMERSEM parameters were tested with analysis of variance (ANOVA), or with Kruskal-Wallis tests when the assumptions of ANOVA were not met. StudentNewman-Keuls or Dunn's tests were used for parametric and non-parametric multiple comparisons (Zar 1999).

\section{RESULTS}

\section{Otolith microstructure}

The otolith microstructure was clearer in summer, and daily increments were well-defined compared to autumn and winter (Fig. 2). Larvae caught in winter
(February) had the faintest microstructure, with daily increments that were hard to distinguish (Fig. 2). The distance of the hatching check from the core was significantly different among summer (4.32 $\mu \mathrm{m})$, autumn $(4.44 \mu \mathrm{m})$ and winter $(4.59 \mu \mathrm{m}$; ANOVA, $F=$ $25.73, p<0.001$ ). The first few (up to 10) increments, in all 3 seasons, were the narrowest encountered on the otoliths $(0.9-2 \mu \mathrm{m})$ and appeared as faint concentric rings of alternating dark and light zones around the core (see also Palomera et al. 1988, Aldanondo et al. 2008). Sub-daily units, thin and faint, appeared quite early; however, they were easy to discriminate from the daily increments. As the distance from the nucleus increased, daily increments widened and rings were replaced by groups of microincrements, as described by Cermeño et al. (2008). The increase in increment widths occurred faster in the summer group. In summer and autumn, increment widths increased continuously with age, whereas in winter, they reached a plateau after the first $30 \mathrm{~d}$ (Fig. 3). The maximum observed increment width was much lower in the winter group $(7.5 \mu \mathrm{m})$, compared to those of the summer and autumn groups (11 and $21 \mu \mathrm{m}$, respectively).

\section{Age and growth}

Age readings ranged from 12 to $42 \mathrm{~d}$ for the summer group, 24 to $56 \mathrm{~d}$ for the autumn group and 41 to $78 \mathrm{~d}$ for the winter group. Calculation of hatch dates indicated that larvae hatched mainly from mid-June to mid-July 2007 (summer group; S07), mid-October to mid-November 2007 (autumn group; A07) and in December 2008 to early January 2009 (winter group; W09). Fish in summer and autumn grew in length at the same rate, which was significantly higher than that in winter (SL-on-age relationship; Table 2, Fig. 4). On the other hand, fish from all 3 groups


Fig. 2. Engraulis encrasicolus. Microphotographs of polished sagittae of anchovy larvae from (a) July 2007 (standard length, $\mathrm{SL}=28 \mathrm{~mm}$; age = $36 \mathrm{~d}$ ), (b) December $2007(\mathrm{SL}=30 \mathrm{~mm}$; age = $43 \mathrm{~d})$ and (c) February $2009(\mathrm{SL}=28 \mathrm{~mm}$; age = $57 \mathrm{~d})$. Scale bars: $50 \mu \mathrm{m}$ 




Fig. 3. Engraulis encrasicolus. Mean otolith width at age of anchovy late larvae from the 3 sampling periods. Error bars: standard deviations

Table 2. Engraulis encrasicolus. Results of the analysis of covariance models for the between-season (S07, A07 and W09) comparisons of slopes and intercepts for the selected (best) relationships between standard length (SL), total weight (TW), age and otolith radius (OR). The best relationship is represented by the model with optimum performance in terms of simplicity, explanation of variation $\left(\mathrm{r}^{2}\right)$ and residual properties (normal distribution, homoscedasticity). Significant values $(p<0.05)$ are shown in bold

\begin{tabular}{|c|c|c|c|c|c|c|}
\hline & \multirow{2}{*}{$\begin{array}{c}\text { Best } \\
\text { relationship }\end{array}$} & \multicolumn{2}{|c|}{ Slopes } & \multicolumn{2}{|c|}{ Intercepts } & \multirow{2}{*}{$\begin{array}{l}\text { Results of pair- } \\
\text { wise comparisons }\end{array}$} \\
\hline & & $F$ & $\mathrm{p}$ & $F$ & $\mathrm{p}$ & \\
\hline SL-on-age & Linear & 9.65 & 0.0001 & & & $\mathrm{~S} 07=\mathrm{A} 07>\mathrm{W} 09$ \\
\hline TW-on-age & Log-log & 1.53 & 0.2173 & 73.08 & $<0.0001$ & $\mathrm{~S} 07>\mathrm{A} 07>$ W09 \\
\hline OR-on-age & Log-log & 0.49 & 0.615 & 103.52 & $<0.0001$ & S07 > A07 > W09 \\
\hline TW-on-SL & Log-log & 0.61 & 0.5419 & 82.68 & $<0.0001$ & $\mathrm{~S} 07>\mathrm{A} 07=\mathrm{W} 09$ \\
\hline OR-on-SL & Log-log & 2.94 & 0.0539 & 144.38 & $<0.0001$ & $\mathrm{~S} 07>\mathrm{A} 07=\mathrm{W} 09$ \\
\hline OR-on-TW & Log-log & 2.99 & 0.0517 & 37.65 & $<0.0001$ & $\mathrm{~S} 07>\mathrm{A} 07=\mathrm{W} 09$ \\
\hline
\end{tabular}

annual variability in the timing of peaks) following the entrainment of subsurface nutrients, triggered by the increased vertical mixing in the preceding period (identified by the decrease of PED and the increase of SSS, Fig. 5). Another factor further enhancing biological production in spring is the increased river discharge and associated nutrient inputs that peak during that period. As the temperature of the surface layer increases, water column stratification rises in late spring-summer, and nutrients are entrapped under the thermocline (not shown). As a result, biological production decreases, reaching a minimum in SeptemberDecember (Fig. 5).

Average model-simulated chl a was much lower compared to remotelysensed chl a (Fig. 6). However when comparing the normalized values, modelled chl a presented similar seasonal variability to MODIS (Fig. 6), i.e. increasing during the winterspring period and decreasing in the summer-autumn stratified period.

The simulated average biological production for the sampling periods

gained weight at the same rate, although fish were heavier during summer and lighter during winter (log[TW]-on-log[age]; Table 2, Fig. 4). Otolith growth rates did not differ significantly among groups, but otoliths were bigger at age in summer and smaller in winter (log[OR]-on-log[age]; Table 2, Fig. 4), exhibiting the same pattern as somatic growth in weight. The relationships of $\log (\mathrm{TW})$-on- $\log (\mathrm{SL}), \log (\mathrm{OR})$-on$\log (\mathrm{SL})$ and $\log (\mathrm{OR})$-on-log(TW) were highly significant $\left(r^{2} \geq 0.897\right)$ for all 3 groups. Their slopes were not significantly different among seasons; however, in summer, fish were heavier at length and had bigger otoliths for the same length and weight (Table 2, Fig. 4) compared to autumn and winter.

\section{Oceanographic conditions}

The model-simulated variability in the physical environment (SST, SSS, PED) and biological production (chl a, micro- and mesozooplankton biomass) is shown in Fig. 5. Higher biological production is simulated for the period March to April (with some inter- exhibited a different seasonal pattern compared to the in situ data from the sampling surveys. The latter exhibited higher chl $a$ and mesozooplankton biomass in December and higher microzooplankton biomass in February (Table 1). According to the POM-ERSEM simulation, anchovy larvae experienced higher plankton productivity in February and the lowest in December (Fig. 5).

In Fig. 7, box-and-whisker plots of the selected environmental parameters for the period prior to sampling (equal to maximum age reported in the respective larval sample) are presented. According to the oceanographic model, larvae caught in summer experienced, on average, significantly warmer, less saline waters with high water column stratification during their development (Table 3, Fig. 7). Larvae caught in February developed in cold and well mixed waters. The conditions for larvae caught in December were intermediate (initial phase of the mixing period). Simulated chl a and zooplankton biomasses were higher for the summer-caught larvae, whereas both micro- and mesozooplankton were significantly higher in December than in February. 

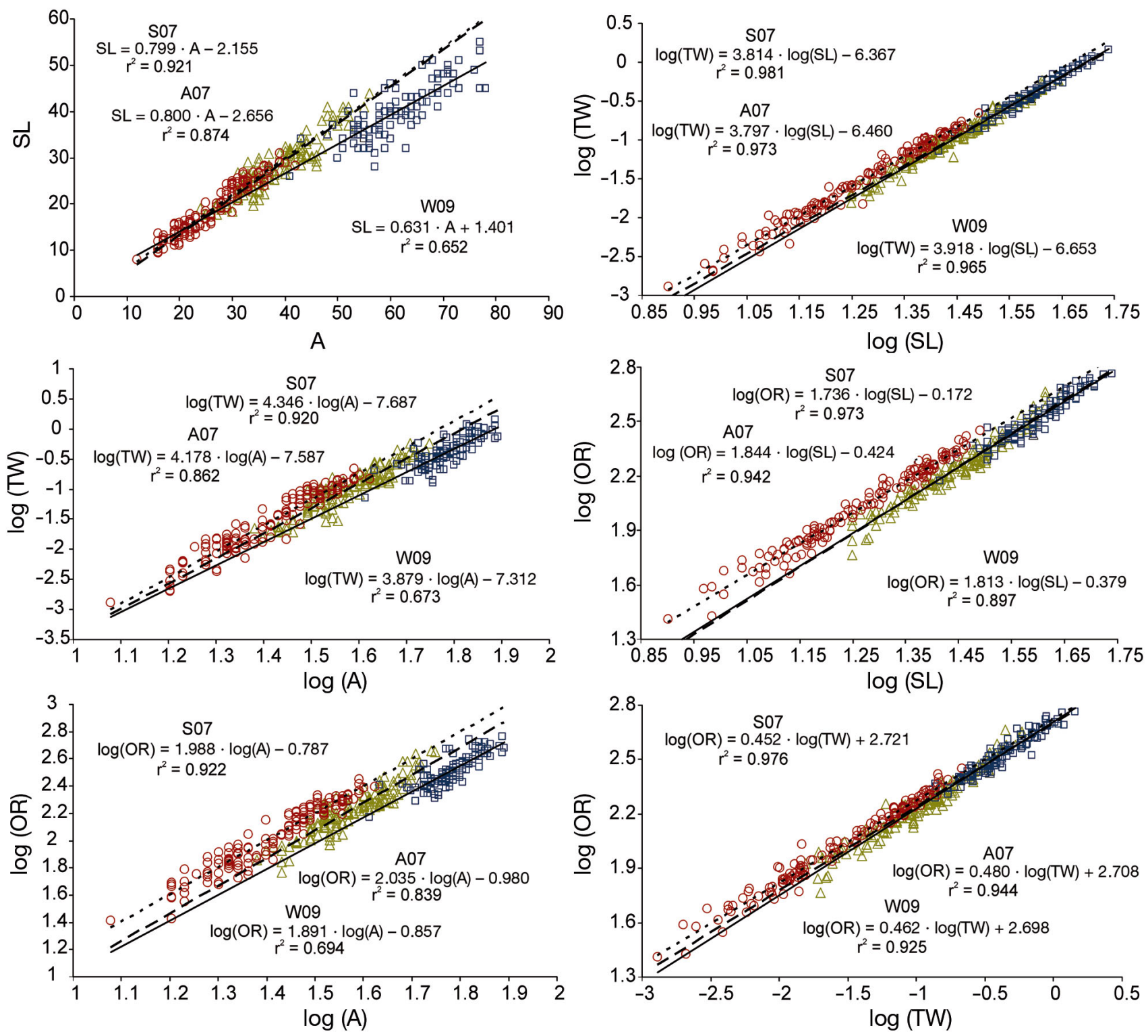

Fig. 4. Engraulis encrasicolus. Relationships between standard length (SL), total weight (TW), age (A) and otolith radius (OR) for July 2007 (S07, circles), December 2007 (A07, triangles) and February 2009 (W09, squares)

Table 3. Comparison of average POM-ERSEM outputs in the broader area of sampling during the period prior to sampling (equal to maximum age in the larval sample) in S07, A07 and W09. Medians and the Kruskal-Wallis statistic $(H)$ are given. All $H$ values are significant at $\mathrm{p}<0.001$. Results of the pairwise comparisons (Dunn's tests) are also given: $\mathrm{a}>\mathrm{b}>\mathrm{C}$

\begin{tabular}{|c|c|c|c|c|}
\hline & S07 & A07 & W09 & $H$ \\
\hline Surface temperature $\left({ }^{\circ} \mathrm{C}\right)$ & $25.85^{\mathrm{a}}$ & $17.46^{\mathrm{b}}$ & $14.76^{\mathrm{c}}$ & 134.18 \\
\hline Surface salinity & $35.30^{c}$ & $36.20^{\mathrm{b}}$ & $36.70^{\mathrm{a}}$ & 133.02 \\
\hline Potential energy deficit $(\mathrm{J})$ & $246.96^{\mathrm{a}}$ & $95.81^{\mathrm{b}}$ & $24.53^{\mathrm{c}}$ & 154.49 \\
\hline Mean chl $a$ in water column $\left(\mathrm{mg} \mathrm{C} \mathrm{m}^{-2}\right)$ & $12.42^{\mathrm{a}}$ & $9.25^{\mathrm{b}}$ & $9.28^{\mathrm{b}}$ & 73.90 \\
\hline Mesozooplankton biomass (mg $\mathrm{C} \mathrm{m}^{-2}$ ) & $323.00^{\mathrm{a}}$ & $230.00^{\mathrm{b}}$ & $216.00^{\mathrm{c}}$ & 68.22 \\
\hline Microzooplankton biomass (mg $\mathrm{C} \mathrm{m}^{-2}$ ) & $312.00^{\mathrm{a}}$ & $162.00^{\mathrm{b}}$ & $128.00^{\mathrm{c}}$ & 71.63 \\
\hline
\end{tabular}

\section{DISCUSSION}

In this study, we investigated the growth rates of European anchovy late larvae that hatched in the peak of (June-July), the end of (October-November) and also after (December) the regular anchovy spawning period. In order to explain the observed differences in otolith microstructure and somatic growth as well as somatic condition, we examined the output of a coupled 




Fig. 5. Daily predictions of the coupled hydrodynamic-biogeochemical model (POM-ERSEM) implemented in the North Aegean Sea, averaged over the wider area of sampling (indicated in Fig. 1 and up to the $300 \mathrm{~m}$ isobath) from January 2007 to February 2009. Shaded areas represent the periods prior to sampling equal to maximum age of larvae caught in July 2007, December 2007 and February 2009 biophysical model (POM-ERSEM) to obtain a better understanding of the potential environment in which these individuals lived during the course of their development.

The analysis of larvae collected in February 2009 indicated that the 2008 spawning period of anchovy in the North Aegean Sea was unexpectedly extended, lasting until early January. Recently, Costalago et al. (2011) also reported unexpected capture of anchovy late larvae in December in the Gulf of Lions; subsequent otolith analysis confirmed that these anchovies were born well after the usual end of the spawning season in the NW Mediterranean, i.e. in late autumn. In the Mediterranean Sea, anchovy spawning generally takes place from May to October (Regner 1996, Somarakis et al. 2004, Palomera et al. 2007); however, in the central Aegean Sea, eggs have been sampled even in December (Somarakis et al. 2006). In the warmer Israeli waters, Walline (1987) captured anchovy larvae all year round. Over the last decades, the Mediterranean Sea surface has been continuously warming, and since the early 1990s, the heating rate has accelerated (Skliris et al. 2012). As the duration of the anchovy spawning period is closely related to temperature (Garcia \& Palomera 1996, Regner 1996), extended reproductive seasons may become more common in the future.

Protracted spawning periods are characteristic of multiple spawning fish. It has evolved as an adaptation to ensure progeny survival by dispersing the risk of spawning under unfavourable conditions (Bye 1984, McEvoy \& McEvoy 1992). In our study, anchovies born earlier in the season (summer sample) were in better condition compared to the autumn and winter groups (log[TW]-on-log[SL]; Fig. 4). Several authors reported that earlyand mid-spawned larvae exhibited higher survivorship than those born later in the season (Methot 1983, Cargnelli \& Gross 1996, Wright \& Gibb 2005). Cargnelli \& Gross (1996) suggested that early hatching maximizes the period of 

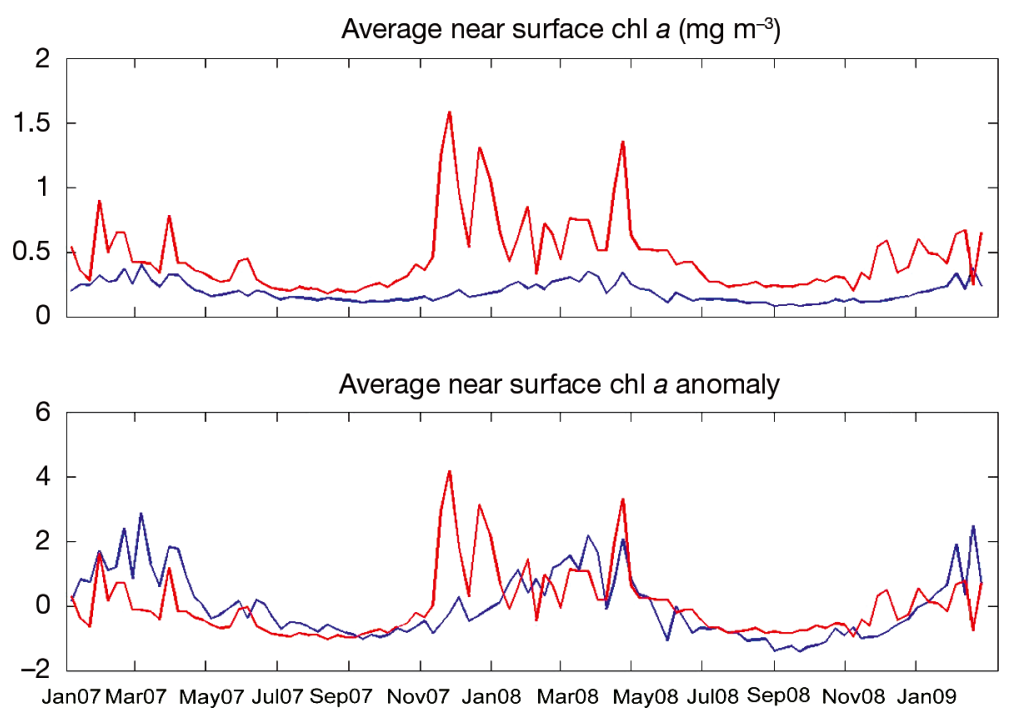

Fig. 6. Plots of simulated (blue line) and satellite-derived (red line) nearsurface chlorophyll a (upper panel) and corresponding normalized values (lower panel)

increased growth which can be an important advantage in size-dependent over-winter mortality. Thus, it can be argued that, assuming that predation rates and transport to unfavourable areas remain unchanged temporally, anchovy larvae that hatch early in the spawning season in the Aegean Sea may have higher chances of survival.

In winter, fish were larger (longer) at hatching compared to summer and autumn (log[SL]-onlog[age]; Fig. 4). Additionally, the hatch check was deposited at a longer distance from the otolith primordium compared to the other 2 groups. Both larval length and otolith size at hatching are strongly correlated with egg size (Marteinsdottir \& Steinarsson 1998, Nissling et al. 1998, Høie et al. 1999). In anchovy, it is well documented that egg size decreases during the spawning season, probably due to temperature increase (Hunter \& Leong 1981, Clarke 1989, Motos 1996). However, in experiments with Japanese anchovy kept in tanks, Tsuruta \& Hirose (1989) showed that when the spawning period extends to autumn-winter, egg size gradually increases again as the temperature falls. This conforms to our findings of bigger otolith and larval size at hatching towards the end of spawning season when temperature decreased.

Otolith microstructure differed markedly between seasons, and this was obvious by simple visual examination of the otoliths under the microscope. Increments were wider and well-defined in summer, while in winter they were narrow and faint (Figs. $2 \& 3$ ). In the Gulf of Lions, Costalago et al. (2011) observed a similar pattern of very narrow daily increments with relatively unvarying widths in the otoliths of anchovy larvae caught in December (average sea surface temperature: $12.64^{\circ} \mathrm{C}$ ). In rearing experiments with Engraulis encrasicolus larvae held in tanks at different temperatures, Aldanondo et al. (2008) found that increment deposition was very low at $17.6^{\circ} \mathrm{C}$. Laboratory experiments with juveniles of the Japanese anchovy E. japonicus using different temperature levels and/or food rations (Namiki et al. 2010) showed that low temperatures $\left(13-14^{\circ} \mathrm{C}\right)$ and limited food intake influence increment widths. The latter authors argued that low water temperatures cause the lowering of contrast between discontinuous and incremental zones of otolith increments leading to unclear daily deposition patterns. These experiments conform to our observations of narrow

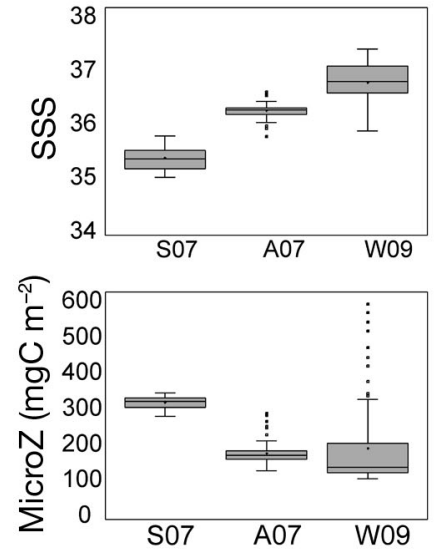

Fig. 7. POM-ERSEM output for the study area in the period prior to sampling (equal to the maximum reported age of larvae) for S07, A07 and W09. SST: sea surface temperature, PED: potential energy deficit, SSS: sea surface salinity, MesoZ (MicroZ): meso(micro)zooplankton 
increments and faint otolith microstructure for anchovy larvae in the North Aegean Sea caught in February (average model-predicted temperature: $\left.14.76^{\circ} \mathrm{C}\right)$.

The otolith growth rates were similar among seasons, but otoliths were bigger for the same age in summer and also significantly larger for the same fish length or weight (Fig. 4). Several authors have reported that otoliths continue to grow even in temperatures above the optimum for somatic growth (Mosegaard et al. 1988, Otterlei et al. 2002, Folkvord et al. 2004, Fey 2006). This uncoupling between otolith and somatic growth at high temperatures has been attributed to the closer relation of otolith growth to metabolic rates, which continuously increase with increasing temperature, rather than to somatic growth rates (Wright et al. 1990, Wright 1991). Thus, the use of otolith growth as a proxy for somatic growth in anchovy, e.g. in individual based models (Allain et al. 2003, 2007), may not be so realistic, especially when scenarios with high temperatures are being tested.

The mean growth rates estimated in this study were high (Fig. 4), especially for the summer and autumn group $\left(0.80 \mathrm{~mm} \mathrm{~d}^{-1}\right)$, and slightly lower during winter $\left(0.63 \mathrm{~mm} \mathrm{~d}^{-1}\right)$. European anchovy growth rate during the early larval stages has been studied extensively, and estimated growth rates varied from 0.42 to $0.97 \mathrm{~mm} \mathrm{~d}^{-1}$ (Palomera et al. 2007, Somarakis \& Nikolioudakis 2007, and references therein); however, information on the growth of larger larvae is scarce. In the Adriatic Sea, growth of late larvae/ early juveniles (length range: $10-60 \mathrm{~mm}$ ) fluctuated seasonally from $0.82 \mathrm{~mm} \mathrm{~d}^{-1}$ in May to $0.55 \mathrm{~mm} \mathrm{~d}^{-1}$ in November (La Mesa et al. 2009). In the Bay of Biscay, juvenile growth was also quite variable, ranging from $0.88 \mathrm{~mm} \mathrm{~d}^{-1}$ in off-shore waters to $0.32 \mathrm{~mm} \mathrm{~d}^{-1}$ close to the Gironde River plume (length range: 33-106 and 44-137 mm, respectively; Aldanondo et al. 2010). In both studies, the differences in growth rates were mainly attributed to seasonal and spatial variations in temperature.

The high growth rates combined with the fact that fish were heavier at the same age and length in summer (Fig. 4) indicate better conditions compared to autumn or winter. As simulated by the coupled hydrodynamic-biogeochemical model, larvae caught in summer developed in waters that were, on average, not only warmer but also more stratified, less saline and highly productive in terms of both phytoplankton and zooplankton (Fig. 7, Table 3). In the oligotrophic Mediterranean Sea, the suitable habitats for anchovy early stages have been associated with stabilized water masses of low salinity and high productivity (Agostini \& Bakun 2002). In the Aegean Sea, such conditions are mainly generated by inputs of fresher waters like the Black Sea water, which enters into the Aegean Sea through the Dardanelles Straits, and the discharge from local rivers (Isari et al. 2006, 2007, Somarakis \& Nikolioudakis 2007).

The simulated seasonal variability in biological production was verified here using remotely-sensed chl a data (Fig. 6). The significant short-term variability during the season of high primary production, particularly evident in the satellite data from November 2007 to May 2008, could be attributed to variability in river runoff that is related to rainfall (higher during this period). This short-term runoff variability is not taken into account in the ERSEM simulation that adopts a climatological seasonal river runoff variation (see 'Materials and methods').

When examining the in situ measurements of environmental parameters, the picture obtained for primary and secondary productivity was quite different, compared to the model simulation of recent environmental history (Tables 1 \& 3). Hence, seasonal changes of growth in weight and somatic condition could not be explained by current/local environmental conditions. The use of a model simulation allowed for a more realistic representation of the environment that larvae may have experienced during their development (environmental history), compared to the instantaneous image that was provided by the in situ measurements (current environmental conditions). As shown by the simulation (Fig. 5), the environmental conditions may exhibit significant changes during the period of larval development, particularly during the winter-spring bloom period. Moreover, the broader area of sampling that was used for averaging model parameters was probably more representative of the larval habitat, as compared to the location of the in situ measurements (very near the mouth of the Nestos River) where environmental conditions are directly driven by the variability of river outflow. It must be noted, however, that this approach (averaging environmental parameters over a broader area) also introduces some degree of variability.

In individual based models, some authors have used backward drift trajectories of larvae (i.e. trajectories of larvae from the point of capture to the point of hatching based on hydrodynamic model fields) to reconstruct the daily larval positions and relate otolith widths with the conditions that larvae experienced during their drift (Allain et al. 2003, 2007, Hinrichsen et al. 2010). This approach is based on the assumption that larvae represent passive particles, 
which is most likely true for early larvae but not for the postflexion larval stage that is the focus of the present study. The completion of notochord flexion has been associated with significant improvement in swimming performance, i.e. higher speed and endurance (Clark et al. 2005), and behavioural capabilities; thus, considering late larvae as passive particles might not be so realistic (Leis 2007, Irigoien et al. 2008, Somarakis \& Nikolioudakis 2010).

In conclusion, the use of the biophysical model outputs greatly assisted in explaining the seasonal changes in growth, condition and otolith microstructure of late anchovy larvae. The use of such models in interpreting changes in larval growth and condition and identifying temporal windows of increased growth and survival will probably become very popular in the future as such models are being implemented, validated and becoming operational in most regional seas around the world (e.g. Kishi et al. 2007, Siddorn et al. 2007, Lazzari et al. 2012).

Acknowledgements. Part of this work was supported by the European project SARDONE (Improving assessment and management of small pelagic species in the Mediterranean, FP6-44294). This work was also financially supported by the General Secretariat of Research and Technology, Greece, through the project 'REcruitment PROcesses Using Coupled biophysical models of the pelagic Ecosystem - Marifish' within the framework of the EU ERA-Net initiative (6th Framework Programme). We thank A. Machias, M. Giannoulaki, K. Tsagkarakis, N. Nikolioudakis and the captain and crew of the RV 'Philia' for their help during the sampling cruises. Thanks also to the SARDONE 'growth team' for the preparation of common otolith interpretation protocols. Finally, we thank the 3 anonymous reviewers and the Editor, A. Gallego, for their constructive comments.

\section{LITERATURE CITED}

Agostini VN, Bakun A (2002) 'Ocean triads' in the Mediterranean Sea: physical mechanisms potentially structuring reproductive habitat suitability (with example application to European anchovy, Engraulis encrasicolus). Fish Oceanogr 11:129-142

> Aldanondo N, Cotano U, Etxebeste E, Irigoien X, Alvarez P, Martinez de Murguia A, Herrero DL (2008) Validation of daily increments deposition in the otoliths of European anchovy larvae (Engraulis encrasicolus L.) reared under different temperature conditions. Fish Res 93: 257-264

Aldanondo N, Cotano U, Tiepolo M, Boyra G, Irigoien X (2010) Growth and movement patterns of early juvenile European anchovy (Engraulis encrasicolus L.) in the Bay of Biscay based on otolith microstructure and chemistry. Fish Oceanogr 19:196-208

Aldanondo N, Cotano U, Etxebeste E (2011) Growth of young-of-the-year European anchovy (Engraulis encrasicolus L.) in the Bay of Biscay. Sci Mar 75:227-235

> Allain G, Petitgas P, Grellier P, Lazure P (2003) The selection process from larval to juvenile stages of anchovy (Engraulis encrasicolus) in the Bay of Biscay investigated by Lagrangian simulations and comparative otolith growth. Fish Oceanogr 12:407-418

Allain G, Petitgas P, Lazure P, Grellier P (2007) Biophysical modelling of larval drift, growth and survival for the prediction of anchovy (Engraulis encrasicolus) recruitment in the Bay of Biscay (NE Atlantic). Fish Oceanogr 16: 489-505

Anderson JT (1988) A review of size dependent survival during pre-recruit stages of fishes in relation to recruitment. J Northwest Atl Fish Sci 8:55-66

Baretta JW, Ebenhoh W, Ruardij P (1995) The European Regional Seas Ecosystem Model, a complex marine ecosystem model. Neth J Sea Res 33:233-246

Blumberg AF, Mellor GL (1983) Diagnostic and prognostic numerical circulation studies of the South Atlantic Bight. J Geophys Res 88:4579-4592

Bye VJ (1984) The role of environmental factors in the timing of reproductive cycles. In: Potts GW, Wootton RJ (eds) Fish reproduction: strategies and tactics. Academic Press, London, p 181-206

> Cargnelli LM, Gross MR (1996) The temporal dimension in fish recruitment: birth date, body size, and sizedependent survival in a sunfish (bluegill: Lepomis macrochirus). Can J Fish Aquat Sci 53:360-367

> Cermeño P, Uriarte A, Martinez de Murguia A, Morales-Nin B (2003) Validation of daily increment formation in otoliths of juvenile and adult European anchovy. J Fish Biol 62:679-691

Cermeño P, Morales-Nin B, Uriarte A (2006) Juvenile European anchovy otolith microstructure. Sci Mar 70:553-557

> Cermeño P, Uriarte A, Morales-Nin B, Cotano U, Álvarez P (2008) Setting up interpretation criteria for ageing juvenile European anchovy otoliths. Sci Mar 72:733-742

Clark DL, Leis JM, Hay AC, Trnski T (2005) Swimming ontogeny of larvae of four temperate marine fishes. Mar Ecol Prog Ser 292:287-300

Clarke TA (1989) Seasonal differences in spawning, egg size, and early development time of the Hawaiian anchovy or nehu, Encrasicholina purpurea. Fish Bull 87:593-600

> Costalago D, Tecchio S, Palomera I, Alvarez-Calleja I, Ospina-Alvarez A, Raicevich S (2011) Ecological understanding for fishery management: condition and growth of anchovy late larvae during different seasons in the Northeastern Mediterranean. Estuar Coast Shelf Sci 93: 350-358

> Dulcic J (1995) Estimation of age and growth of sardine, Sardina pilchardus (Walbaum, 1792), larvae by reading daily otolith increments. Fish Res 22:265-277

Fey DP (2006) The effect of temperature and somatic growth on otolith growth: the discrepancy between two clupeid species from a similar environment. J Fish Biol 69: 794-806

> Folkvord A, Johannessen A, Moksness E (2004) Temperature-dependent otolith growth in Norwegian springspawning herring (Clupea harengus L.) larvae. Sarsia 89: 297-310

Fréon P, Cury P, Shannon L, Roy C (2005) Sustainable exploitation of small pelagic fish stocks challenged by environmental and ecosystem changes: a review. Bull Mar Sci 76:385-462

Garcia A, Palomera I (1996) Anchovy early life history and its relation to its surrounding environment in the Western Mediterranean basin. Sci Mar 60:155-166 
Heath MR (1992) Field investigations of the early life stages of marine fish. Adv Mar Biol 28:1-174

Høie H, Folkvord A, Johannessen A (1999) Maternal, paternal and temperature effects on otolith size of young herring (Clupea harengus L.) larvae. J Exp Mar Biol Ecol 234:167-184

Hinrichsen HH, Voss R, Huwer B, Clemmesen C (2010) Variability of larval Baltic sprat (Sprattus sprattus L.) otolith growth: a modeling approach combining spatially and temporally resolved biotic and abiotic environmental key variables. Fish Oceanogr 19:463-479

Houde ED (1989) Comparative growth, mortality, and energetics of marine fish larvae: temperature and implied latitudinal effects. Fish Bull 87:471-495

Hunter JR, Leong R (1981) The spawning energetics of female northern anchovy, Engraulis mordax. Fish Bull 79:215-230

IOCCG (International Ocean-Colour Coordinating Group) (2000) Remote sensing of ocean colour in coastal, and other optically-complex waters. In: Sathyendranath S (ed) Rep Int Ocean-Colour Coord Group 3. IOCCG, Dartmouth, NS

> Irigoien X, Cotano U, Boyra G, Santos M and others (2008) From egg to juvenile in the Bay of Biscay: spatial patterns of anchovy (Engraulis encrasicolus) recruitment in a nonupwelling region. Fish Oceanogr 17:446-462

> Isari S, Ramfos A, Somarakis S, Koutsikopoulos C, Kallianiotis A, Fragopoulu N (2006) Mesozooplankton distribution in relation to hydrology of the Northeastern Aegean Sea, Eastern Mediterranean. J Plankton Res 28:241-255

Isari S, Psarra S, Pitta P, Mara P and others (2007) Differential patterns of mesozooplankters' distribution in relation to physical and biological variables of the northeastern Aegean Sea (eastern Mediterranean). Mar Biol 151: 1035-1050

Kishi MJ, Kashiwai M, Ware DM, Bernard A and others (2007) NEMURO - a lower trophic level model for the North Pacific marine ecosystem. Ecol Model 202:12-25

Korres G, Nittis K, Perivoliotis L, Tsiaras K, Papadopoulos A, Triantafyllou G, Hoteit I (2010) Forecasting the Aegean Sea hydrodynamics within the POSEIDON-II operational system. J Oper Oceanogr 3:37-49

Kourafalou VH, Barbopoulos KA (2003) High resolution simulations on the North Aegean Sea seasonal circulation. Ann Geophys 21:251-265

> Kourafalou VH, Tsiaras K (2007) A nested circulation model for the North Aegean Sea. Ocean Sci 3:1-16

> La Mesa M, Donato F, Giannetti G, Arneri E (2009) Growth and mortality rates of European anchovy (Engraulis encrasicolus) in the Adriatic Sea during the transition from larval to juvenile stages. Fish Res 96:275-280

- Lazzari P, Solidoro C, Ibello V, Salon S and others (2012) Seasonal and inter-annual variability of plankton chlorophyll and primary production in the Mediterranean Sea: a modeling approach. Biogeosciences 9:217-233

> Leggett WC, DeBlois E (1994) Recruitment in marine fishes: Is it regulated by starvation and predation in the egg and larval stages? Neth J Sea Res 32:119-134

Leis JM (2007) Behaviour as input for modelling dispersal of fish larvae: Behaviour, biogeography, hydrodynamics, ontogeny, physiology and phylogeny meet hydrography. Mar Ecol Prog Ser 347:185-193

Marteinsdottir G, Steinarsson A (1998) Maternal influence on the size and viability of Iceland cod Gadus morhua eggs and larvae. J Fish Biol 52:1241-1258
McEvoy LA, McEvoy J (1992) Multiple spawning in several commercial fish species and its consequences for fisheries management, cultivation and experimentation. J Fish Biol 41:125-136

Methot RD Jr (1983) Seasonal variation in survival of larval northern anchovy, Engraulis mordax, estimated from the age distribution of juveniles. Fish Bull 81:741-750

Mosegaard H, Svedäng H, Taberman K (1988) Uncoupling of somatic and otolith growth rates in Arctic char (Salvelinus alpinus) as an effect of differences in temperature response. Can J Fish Aquat Sci 45:1514-1524

Motos L (1996) Reproductive biology and fecundity of the Bay of Biscay anchovy population (Engraulis encrasicolus L.). Sci Mar 60:195-207

Namiki S, Tanaka H, Katayama S, Funaki O, Aoki I, Oozeki $\mathrm{Y}$ (2010) Validation of daily increment formation in otoliths of immature and adult Japanese anchovy Engraulis japonicus. Fish Sci 76:951-959

Nikolioudakis N, Palomera I, Machias A, Somarakis S (2011) Diel feeding intensity and daily ration of the sardine Sardina pilchardus. Mar Ecol Prog Ser 437:215-228

> Nissling A, Larsson R, Vallin L, Frohlund K (1998) Assessment of egg and larval viability in cod, Gadus morhua: methods and results from an experimental study. Fish Res 38:169-186

Nittis K, Perivoliotis L, Korres G, Tziavos C, Thanos I (2006) Operational monitoring and forecasting for marine environmental applications in the Aegean Sea. Environ Model Softw 21:243-257

Otterlei E, Folkvord A, Nyhammer G (2002) Temperature dependent otolith growth of larval and early juvenile Atlantic cod (Gadus morhua). J Mar Sci 59:851-860

> Palomera I, Morales-Nin B, Lleonart J (1988) Larval growth of anchovy, Engraulis encrasicolus in the Western Mediterranean Sea. Mar Biol 99:283-291

Palomera I, Olivar MP, Salat J, Sabates A, Coll M, Garcia A, Morales-Nin B (2007) Small pelagic fish in the NW Mediterranean Sea: an ecological review. Prog Oceanogr 74: 377-396

Papadopoulos A, Kallos G, Katsafados P, Nickovic S (2002) The Poseidon weather forecasting system: an overview. Global Atmos Ocean Syst 8:219-237

Petihakis G, Triantafyllou G, Allen IJ, Hoteit I, Dounas C (2002) Modelling the spatial and temporal variability of the Cretan Sea ecosystem. J Mar Syst 36:173-196

> Planque B, Bellier E, Lazure P (2007) Modelling potential spawning habitat of sardine (Sardina pilchardus) and anchovy (Engraulis encrasicolus) in the Bay of Biscay. Fish Oceanogr 16:16-30

> Politikos D, Triantafyllou GN, Petihakis G, Tsiaras K, Somarakis S, Ito SI, Megrey BA (2011) Application of a bioenergetics growth model for European anchovy (Engraulis encrasicolus) linked with a lower trophic level ecosystem model. Hydrobiologia 670:141-163

> Poulos SE, Drakopoulos PG, Collins MB (1997) Seasonal variability in sea surface oceanographic conditions in the Aegean Sea (Eastern Mediterranean): an overview. J Mar Syst 13:225-244

Regner S (1996) Effects of environmental changes on early stages and reproduction of anchovy in the Adriatic Sea. Sci Mar 60:167-177

Secor DH, Dean JM, Laban EH (1992) Otolith removal and preparation for microstructural examination. In: Stevenson DK, Campana SE (eds) Otolith microstructure examination and analysis. Can Spec Publ Fish Aquat Sci 
117:19-57

Siddorn JR, Allen JI, Blackford JC, Gilbert FJ and others (2007) Modelling the hydrodynamics and ecosystem of the North-West European continental shelf for operational oceanography. J Mar Syst 65:417-429

Skliris N, Sofianos S, Gkanasos A, Mantziafou A, Vervatis V, Axaopoulos P, Lascaratos A (2012) Decadal scale variability of sea surface temperature in the Mediterranean Sea in relation to atmospheric variability. Ocean Dyn 62: 13-30

Skoulikidis N (2009) The environmental state of rivers in the Balkans - a review within the DPSIR framework. Sci Total Environ 407:2501-2516

Somarakis S, Nikolioudakis N (2007) Oceanographic habitat, growth and mortality of larval anchovy (Engraulis encrasicolus) in the northern Aegean Sea (eastern Mediterranean). Mar Biol 152:1143-1158

Somarakis S, Nikolioudakis N (2010) What makes a late anchovy larva? The development of the caudal fin seen as a milestone in fish ontogeny. J Plankton Res 32:317-326

Somarakis S, Kostikas I, Peristeraki N, Tsimenides N (1997) Fluctuating asymmetry in the otoliths of larval anchovy Engraulis encrasicolus and the use of developmental instability as an indicator of condition in larval fish. Mar Ecol Prog Ser 151:191-203

Somarakis S, Palomera I, Garcia A, Quintanilla L, Koutsikopoulos C, Uriarte A, Motos L (2004) Daily egg production of anchovy in European waters. ICES J Mar Sci 61:944-958

Somarakis S, Tsianis DE, Machias A, Stergiou KI (2006) An overview of biological data related to anchovy and sardine stocks in Greek waters. In: Palomares MLD, Stergiou KI, Pauly D (eds) Fishes in databases and ecosystems. Fish Cent Res Rep 14. Fisheries Centre, University of British Columbia, Vancouver, BC, p 56-64

Therianos AD (1974) Rainfall and geographical distribution of river runoff in Greece. Bull Geol Soc Greece XI:28-58 (in Greek)

Triantafyllou G, Hoteit I, Korres G, Petihakis G (2005) Eco-

Editorial responsibility: Alejandro Gallego,

Aberdeen, UK system modeling and data assimilation of physicalbiogeochemical processes in shelf and regional areas of the Mediterranean Sea. Appl Numer Anal Comput Math 2:262-280

Tsiaras K, Korres G, Petihakis G, Nittis K, Raitsos D, Pollani A, Triantafyllou G (2010) The Poseidon ecosystem model: the Mediterranean case. In: Dahlin H, Bell MJ, Flemming NC, Petersson SE (eds) Coastal to Global Operational Oceanography: Achievements and Challenges. Proceedings of the Fifth International Conference on EuroGOOS. EuroGOOS Office SMHI, Norrköping/Bundesamt für Seeschifffahrt und Hydrographie (BSH) EuroGOOS publication 28, p 191-198

Tsiaras K, Kourafalou VH, Raitsos D, Triantafyllou G, Petihakis G, Korres G (2012) Inter-annual productivity variability in the North Aegean Sea: influence of thermohaline circulation during the Eastern Mediterranean Transient. J Mar Syst 96-97:72-81

Tsuruta Y, Hirose K (1989) Internal regulation of reproduction in the Japanese anchovy (Engraulis japonicus) as related to population fluctuation. In: Beamish RJ, McFarlane GA (eds) Effects of oceanic variability on recruitment and an evaluation of parameters used in stock assessment models. Can Spec Publ Fish Aquat Sci 108: 111-119

Walline P (1987) Growth and ingestion rates of larval fish populations in the coastal waters of Israel. J Plankton Res 9:91-102

Wright PJ (1991) The influence of metabolic rate on otolith increment width in Atlantic salmon parr, Salmo salar L. J Fish Biol 38:929-933

Wright PJ, Gibb FM (2005) Selection for birth date in North Sea haddock and its relation to maternal age. J Anim Ecol 74:303-312

> Wright PJ, Metcalfe NB, Thorpe JE (1990) Otolith and somatic growth rates in Atlantic salmon parr, Salmo salar L.: evidence against coupling. J Fish Biol 36:241-249

Zar JH (1999) Biostatistical analysis, 4th edn. Prentice Hall, Englewood Cliffs, NJ

Submitted: August 31, 2012; Accepted: November 14, 2012 Proofs received from author(s): March 4, 2013 